\title{
Organizational and Competitive Intelligence: Proposal for an Integrated Framework for Business Competitiveness
}

\author{
Orandi Mina Falsarella \\ Celeste Aída Sirotheau Corrêa Jannuzzi \\ Teachers and researchers \\ Pontifical Catholic University of Campinas (PUC-Campinas) \\ Center for Economy and Administration \\ Sustainability Postgraduate Program \\ Brazil
}

\begin{abstract}
1.Abstract
In a competitive environment, the use of information and Organizational and Competitive Intelligence (OCI) should be adopted by organizations as a strategy to seek a competitive advantage. In this context, new Information and Communication Technologies (ICT) as well as the improvement of current ones, and the need for organizations to remain economically, socially and environmentally sustainable, also add value to business strategies, making organizations more competitive. The objective thus of this work is to propose an integrated framework composed of guidelines, based on the concepts of OCI, ICT, and Sustainability, which can be used by organizations in the search for competitive advantage. The study is characterized as exploratory research and the data collection is based on a literature review. As a result, six guidelines that make up the proposed integrated framework are presented and exemplified.
\end{abstract}

Keywords: Organizational and Competitive Intelligence; Information and Communication Technologies; Sustainability.

\section{Introduction}

Institutions are currently facing a systematic increase in competition and, in view of this scenario, seizing opportunities, fighting threats, reducing weaknesses and improving the strengths an institution possesses, seem to be vital for a company to achieve competitive advantage and to continue to operate in the market. The range of this distinguishing potential on the part of the institutions is closely related to the definition of competitive strategies which, according to Thompson, Strickland III and Gamble (2008, p 133) "refers to specific aspects of the strategy to compete successfully and to assert competitive advantage between competitors."

For Jannuzzi and Thalamo (2004), as a fundamental resource of differentiation in this context, it is necessary to use intelligence as a systematic part of the decision-making process. Alves and Falsarella (2009: 316) state that "intelligence, referred to the context of information, is usually related to an effort, to an act of choosing the best alternative among all analyzed, based on the information obtained."

In the present day, the fact that companies have the possibility to access the same information determines that the ease of transforming information into intelligence is distinguished as a relevant condition for an institution to be competitive in the market (FULD, 1994). In this way, intelligence systems, or intelligence programs, are based on the identification of sources, on the collection and handling of information using analytical techniques, and on the management of the decision-making process (JANNUZZI and TÁLAMO, 2004). Falsarella, Jannuzzi and, Sugahara(2014) claim that Organizational and Competitive Intelligence (OCI) is an intelligence system that can contribute to a competitive advantage by facilitating an organization to discover threats and opportunities, strengths, and weaknesses through collection and analysis of information both internal and external to the organization.

In the context of information and intelligence, Information and Communication Technologies (ICT), whether existing or emerging, also contribute to a competitive advantage, since they can optimize business processes; create new products or services; improve internal and external communication; facilitate access to information and provide support to assist the decision-making process. 
In that same context still, another element that appears to favor the achievement of competitive advantage is the concept of sustainability. According to Barbiere et al (2010), the occurrence of companies embracing the context of sustainable development plays an important role in exempting them from responsibility for the social and environmental degradation that is affecting the planet. Associated with this, there is the perception that this theme, as a form of differentiation, can be used as a competitive factor in relation to competitors.

According to Munck and Souza (2009) there are three dimensions of sustainability in the business context. First, the Economic dimension, that seeks competitive advantage, quality improvement, cost reduction, and market focus; second, the Environmental dimension, which is concerned with the use of clean technologies, recycling, sustainable use of natural resources, among others; finally, the Social dimension, that is concerned with social responsibility, support for community growth, commitment to the development of human resources, and the promotion and participation of the company in social projects.

Observing the aforementioned dimensions, some considerations are interesting to point out, e.g, for a company in which economic sustainability is fundamental for its survival, environmental and social sustainability can also be - if achieved - competitive factors. Another important consideration is that if environmental and social sustainability are achieved, this can contribute to achieving economic sustainability since clients and the public will better see the institutional image.

Thus, if we consider the search for competitive advantage, the presented concepts about ICT and sustainability have the same purpose and can complement each other if they are integrated into the context of Organizational and Competitive Intelligence (OCI).

Therefore, the purpose of this work is to propose an integrated framework that can be used by organizations in the search for competitive advantage, composed of guidelines based on the concepts of OCI, ICT, and Sustainability. The proposed work is characterized as exploratory research since it seeks to deepen knowledge about a given fact (GIL, 2002). This type of research is adequate to the proposal for working the relationship between different concepts for the construction of an integrated framework of a practical application since its "main objective is the improvement of ideas or the discovery of intuitions" (GIL, 2002)., p.41). For its development, a bibliographical survey was carried out involving relevant scientific and technical literature, through which it was sought to review the concepts of Organizational and Competitive Intelligence, Information and Communication Technologies and Sustainability, and especially highlight how they contribute to generating a competitive advantage.

\section{Organizational and Competitive Intelligence}

According to Porter (2004), competition has always been a central theme for companies since assessing the environment where an organization operates, knowing competitors, and defining and choosing a competitive position are relevant factors. Motta and Oliveira (2007) corroborate with Porter when they state thatcompetition between organizations exists primarily because one or more current or potential players in a given economic sector perceive the opportunity to improve their position (or establish it) or feel pressured by another player (...). In this context, companies seek to create, develop and sustain advantages over their competitors, in order to allow them to grow and develop in a competitive environment (MOTTA and OLIVEIRA, 2007: 49).

In these two statements, the use of information and intelligence applied to the concept of Organizational and Competitive Intelligence (OCI) can be adopted by organizations as an organizational strategy to seek competitive advantage. The concept of Organizational and Competitive Intelligence (OCI) presented in this work derives from the combination of two other concepts, Organizational Intelligence (IO) and Competitive Intelligence (CI). IO seeks to generate subsidies so that decisions may be taken almost immediately, in the shortest latency time. Starec (2006) states that this is possible as long as the information can be managed strategically. Muller and Castilho (2012) affirm that IO is related to the way in which an organization generates new knowledge that may aid in decision-making and problemsolving. Oliveira (2004) states that IC relates directly to the way an organization monitor the external environment in the search for threats and opportunities. According to Lapa et al. (2015), the objective of the CI is to maintain a continuous process of monitoring the information of the environment in which the company inserts itself, structuring this information in order to generate analyzes that aid in the decision-making process.

Falsarella, Jannuzzi, and Sugahara (2014) affirm that IO and IC are complementary in their propositions since both are concerned with seeking competitive advantage through the strategic management of information, favoring the emergence of the term Organizational and Competitive Intelligence (OCI). According to Alves and Falsarella (2009), the strategic management of information can be accomplished through the OCI cycle, composed of the following stages: 
$\checkmark$ Planning -it determines the field of interest that the organization intends to observe, defines what data and information is relevant, and where the sources where are to be found;

$\checkmark$ Data and Information Collection - the data and information of relevant and reliable internal and external environments are sought after;

$\checkmark$ Analysis - the union of data and information that are related and that can generate intelligence;

$\checkmark$ Dissemination - the delivery of information handled and analyzed to the requesting user.

Given the concepts, managing information, whether external or internal to the organization, or whether it is structured or unstructured, seems to be an interesting contribution to the pursuit of competitive advantage.By monitoring threats and opportunities, strengths, and weaknesses through information collected and analyzed, the decisionmaking process can be more assertive by confiding rather on information than on intuition.

\section{Information and Communication Technologies}

When we refer to existing ICTs, we can quote the different types of Information Systems (SI) presented by LAUDON and LAUDON (2010, p.48), although there are more: Transaction Processing Systems (TPS); Management Information Systems (MIS); Decision Support Systems (DSS); Executive Support Systems (ESS); Enterprise Resource Planning (ERP); Supply Chain Management (SCM) and Business Intelligence (BI) systems. When talking about emerging technologies, some are in evidence, such as Big Data and the Internet of Things (IoT).

Regarding sources of information, Silveira, Marcolin, and Freitas (2015) mention the continuous increase of sources of information external to companies from different kinds of media, information that analyzed could be useful to understand better clients, markets, competitors, suppliers, among others. Begoli and Horey (2012, p.215) add to this statement by saying that in recent years, large amounts of data are available in significant volumes from many sources, such as social networks, social media, calls of mobile devices, scientific activities, simulations, experiments, environmental sensors, etc. in addition to, of course, traditional sources.

In response to this context, a broader concept called Big Data appears in the scientific literature. For Ham (2012), Big Data is the data that should be analyzed by companies, but that was not analyzed then because it could not be processed through the technology that existed in the past. Thus, the Big Data concept can undoubtedly contribute as a competitive factor because it allows the data and information on the amount that they are generated to be analyzed with the necessary speed to aid decision-making.

IoT for one, according to Pacheco, Klein, and Righi (2016), is an opportunity and a challenge for companies of various segments to provide digital capability embedded in products and objects, including cars, televisions, refrigerators, books, etc. so that they offer new functions and applications that enhance its use. Tan (2016) states that IoT is a system of Internet-connected devices that will improve sustainability in a variety of areas, such ase.g. farming. This is demonstrated in the case of California in the United States of America, where almond plantations have sensors that control soil moisture by providing information to the irrigation system, which in turn monitors the need for water saving as much as $20 \%$ on water consumption, as well as improving the quality of production. Whitmore, Agarwal, and $\mathrm{Xu}$ (2015) state that IoT proposes to attach technology to devices used by people in everyday activities, integrating these devices in order to make them accessible by their users through the Internet.

\section{Sustainability}

Gomes and Tortato (2011) argue that achieving a competitive advantage in the face of competition is a priority for companies, especially those operating in a global environment. However, there is a growing counterpoint related to society's concern to seek a balance between economic development, environment, and social justice. Evangelista (2010) corroborates with Gomes and Tortato when inserting the concept of sustainability as a fundamental requirement for the survival of companies in the current context when he affirms that

By seeking more efficient solutions for their own needs and communities, these strategic actors have broken paradigms. It is now assumed that the interests of the market and of society can be convergent, uniting competitiveness and sustainability. It is in this scenario that the concept of sustainability emerges as a basic requirement for the survival of companies in the market (EVANGELISTA, 2010, p.86).

The same author adds to this statement by saying that there are many examples of companies that embed the commitment to social issues in their actions of management and in their internal and external communication, emphasizing the concern with sustainability. These actions of management and communication have the purpose of bringing to the organization a competitive advantage.

Gomes and Tortato (2011) describe that investors assess better the companies considered socially responsible and that environmentalists and communities are attentive to the corporate actions that harm the environment and society. 
The authors also state that sustainable development in the context of corporate sustainability leads to a competitive advantage by reconciling economic viability with social and environmental gains.

Silva and Barbosa (2002) corroborate to this by affirming that economic factors are not so predominant, but that a socially valued behavior that guarantees its legitimacy and survival in the environmental context contributes to the economic sustainability of an organization.

\section{Integrated Framework for Business Competitiveness}

Three concepts can directly contribute to the proposal to create an Integrated Framework for Business Competitiveness (IFBC): (1) Organizational and Competitive Intelligence (OCI), specifically the OCI Cycle; (2) Existing or emerging Information and Communication Technologies (ICT); and (3) sustainability in its three dimensions, economic, social and environmental. Figure 1 illustrates the integration between these concepts through six guidelines.

Figure 1 - Integrated Framework for Business Competitiveness

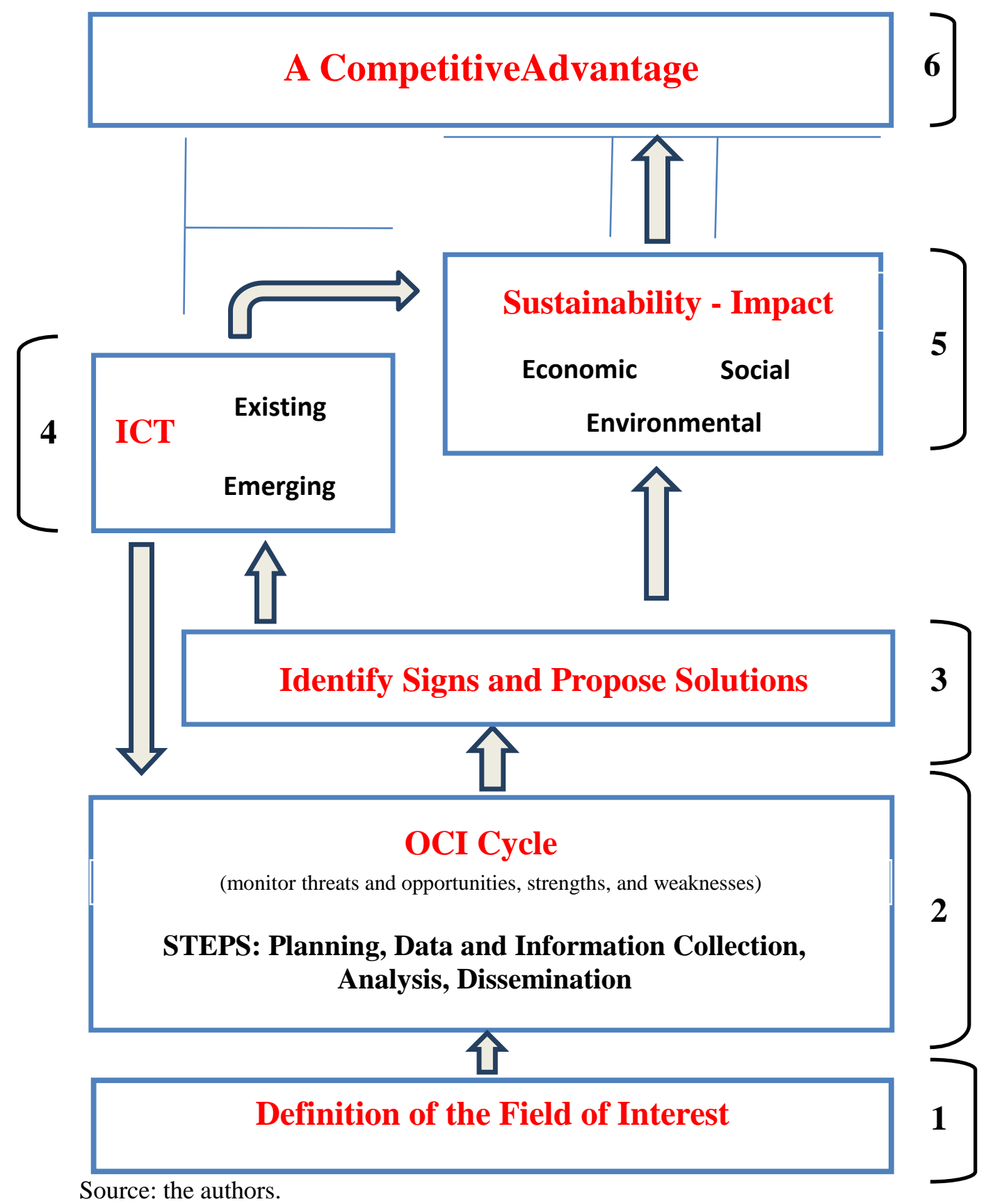


Thefirst guideline is the Definition of the Field of Interest. It indicates what is intended to be observed in order to identify possible threats, opportunities, strengths, and weaknesses. Thesecond guideline is to use the OCI Cycle. In the planning stage, it is identified which information is relevant and where it is in order to identify threats, opportunities, strengths, and weaknesses. In the collection stage, data and information existing in the external and internal environment of the organization are sought after. This part is usually done through Information Systems. In possession of the information, the analysis stage begins, where it is necessary to assess possible relations that can generate some intelligence. After the analysis, the information collected and analyzed is delivered to the requesting user in the dissemination stage of the OCI Cycle. With the information collected and analyzed, the third guideline begins Identifying Signs and Proposing Solutions. The purpose of this guideline is to seek alternatives for the organization to protect itself from threats, seize opportunities, maintain strengths and reduce weaknesses. This work also consists of assessing whether ICTs can be used (ICT guideline) and whether the solutions foundare able to generate some positive impact on sustainability (Impact Sustainability guideline).

In the fourth guideline identified as ICT, it should be assessed whether there are current or emerging Information and Communication Technologies that can contribute in this context. It can be analyzed whether emerging or existing technologies contribute to optimizing some business processes, create new products or services, improve internal and external communication, facilitate access to information and/or provide information to assist the decision-making process.Once the solutions have been identified, the fifth guideline, indicated as Sustainability - Impact, can be initiated. In this guideline, it can be assessed whether the proposed solutions, derived from ICT or not, generate positive or negative impacts in relation to the three dimensions of sustainability, economic, social and environmental. This guideline also intends to improve the solutions adopted by seeking to add actions related to results that contribute to improving the institutional image in relation to sustainability. Finally, given the solutions presented, the sixth guideline, defined as A Competitive Advantage, makes a final assessment and highlights what competitive advantages the organization can achieve with the solutions adopted in the face of threats, opportunities, strengths, and weaknesses. In order to make the proposal clearer and more enlightening, each IFBC guideline will be presented (see Table 1) with examples of how they could be applied and worked out, from the point of view of an organization that acts in the production and sale of parts and equipment directly to consumers.

Table 1 - Application of the integrated framework for business competitiveness

\begin{tabular}{|c|c|c|}
\hline Guideline & Name & Application - Examples \\
\hline $1^{a}$. & Definition of the Field of Interest & $\begin{array}{l}\text { It may be areas of interest such as to learn how competitors attract new customers and what } \\
\text { technologies they are using in the manufacturing, control, and sales process. It may also be } \\
\text { interesting to look at emerging technologies being developed by research centers, consumer } \\
\text { trends, and customer satisfaction. }\end{array}$ \\
\hline $2^{\mathrm{a}}$. & OCI Cycle & $\begin{array}{l}\text { In the planning and collection stages, it is defined in which internal and external databases } \\
\text { this information will be collected. At the analysis stage, Big Data could be used to assess } \\
\text { competitors and their business processes, discover emerging technologies and consumer } \\
\text { trends and, internal systems to detect the level of customer satisfaction. }\end{array}$ \\
\hline $3^{\text {a. }}$. & $\begin{array}{l}\text { Identify Signs } \text { and } \text { Propose } \\
\text { Solutions }\end{array}$ & $\begin{array}{l}\text { By identifying weaknesses in the level of customer satisfaction, a broad process of employee } \\
\text { training could be proposed. The same can happen with a view to improving manufacturing, } \\
\text { control, and sales processes, seeking to optimize them, reducing production and delivery } \\
\text { time to customers. }\end{array}$ \\
\hline $4^{a}$. & $\begin{array}{l}\text { Information and Communication } \\
\text { Technologies - ICT }\end{array}$ & $\begin{array}{l}\text { It could be proposed to implement IOT (Internet of Things) applications, for example, } \\
\text { sensors in the equipment of the production line, so that preventive maintenance could also } \\
\text { be performed when signs of obsolescence or malfunction of parts and components are } \\
\text { identified. This would reduce the downtime of the production line and improve delivery } \\
\text { time. }\end{array}$ \\
\hline $5^{a}$. & Sustainability- Impact & $\begin{array}{l}\text { For each proposed solution, it should be analyzed the impact related to the different } \\
\text { dimensions of sustainability. For example, the use of IoT, besides contributing to increase } \\
\text { the organization's revenues and contribute to economic sustainability, can bring benefits } \\
\text { related to environmental sustainability, if a proposed disposal project is proposed for } \\
\text { sensors, equipment, and parts no longer used. Likewise, employee empowerment has a } \\
\text { positive impact on the social dimension of sustainability. }\end{array}$ \\
\hline $6^{a}$. & ACompetitiveAdvantage & $\begin{array}{l}\text { With all the solutions presented a final assessment should be made in the context of } \\
\text { competitive advantage. For example, the use of IoT may be an opportunity if competitors } \\
\text { have not yet adopted this solution. If a competitor has already deployed this solution, using } \\
\text { this technology can lessen a threat. Another important point in this analysis is to assess the } \\
\text { impact on the three dimensions of sustainability, such as analyzing whether actions related } \\
\text { to environmental sustainability and social sustainability can improve the institutional image } \\
\text { and bring a competitive advantage. }\end{array}$ \\
\hline
\end{tabular}

Source: the authors 


\section{Conclusions}

The Integrated Framework for Business Competitiveness (IFBC), in face of the six guidelines presented, seeks to show another form of analysis and evaluation to achieve a competitive advantage, through the use of the OCI cycle, of current and emerging ICTs and the dimensions of sustainability. The proposal is based mainly on the search and analysis of information since in order to achieve competitive advantage it is necessary to discover threats, opportunities, strengths, and weaknesses. For this, the information treated and analyzed is sought through the definition of the field of interest and the execution of the planning, collection, analysis and dissemination stages of the OCI cycle in order to obtain intelligence to aid the decision-making process. Given the large volume of information currently available and the difficulty of the human being to analyze them, ICT is used for this purpose, facilitating the analysis process and the emergence of values (insights), which can lead to competitive advantage. ICT can also contribute to creating new products or services and/or optimizing business processes, among other possibilities already discussed. In the pursuit of competitive advantage, given that the context of sustainability can contribute to improving the institutional image, this proposal also foresees an analysis of each action on the dimensions of sustainability economic, environmental and social - so that the organization can state and prove that it is concerned with sustainable development. With all of this information and analysis, a final assessment is made of the solutions presented, i.e., whether they can actually bring a competitive advantage. Thus, the proposal for an integrated framework, presented through six guidelines, sought to show how business competitiveness can be achieved through information, Organizational and Competitive Intelligence, the use of Information and Communication Technologies, and the analysis of what each action can cause in the context of sustainability.

\section{Bibliographical References}

Alves, R. P.Falsarella, O. M.(2009).Modelo conceitual de inteligência organizacional aplicada à função manutenção. Gestão e Produção, São Carlos, v. 16, n. 2, 313-324.

Barbiere, J. C. Vasconcelos, I. F. G. Andreassi, T. Vasconcelos, F. C. (2010).Inovação e sustentabilidade: novos modelos e proposições. RAE, São Paulo, v. 50, n. 2, p. 146-154.

Begoli, E. Horey, J. ( 2012).Design principles for effective knowledge discovery from big data. Joint Working Conference on Software Architecture \& 6th European Conference on Software Architecture, IEEE Computer Society, 215-218.

Evangelista, R. (2010). Sustentabilidade: um possível caminho para o sucesso empresarial? Revista Portuguesa e Brasileira de Gestão, v.9 n.1-2, 85-96.

Falsarella, O. M. Jannuzzi, C. A. S. C.Sugarrara, C. R. (2014), Planejamento estratégico empresarial: proposta de um sistema de inteligência organizacional e competitiva. Revista Digital de Biblioteconomia e Ciência da Informação, v. 12, 193-216.

Fuld, L. M. (1994) The new competitor intelligence: the complete resource for finding, analyzing and using information about your competitors. New York: John Wiley\& Sons.

Gil, A.C. (2002). Como elaborar projetos de pesquisa, (4th ed.), São Paulo: Atlas.

Gomes, F. P. Tortato, U. (2011). Adoção de práticas de sustentabilidade como vantagem competitiva: evidências empíricas, Revista Pensamento Contemporâneo em Administração, vol. 5, n. 2, 33-49.

Ham, X. Tian, L.Yoon, M. Lee, M. (2012) A big data model supporting information recommendation in social network. In: International Conference on Cloud and Green Computing, 2., 2012, Hunan, China. IEEE computer society, $810-813$

Jannuzzi, C. A. S. C. Tálamo, M. F. G.M.(2004).A empresa e os sistemas humanos de informação: uma abordagem conceitual para a gestão da informação. Transinformação, Campinas, SP, v. 16, n.16, 171-187.

Lapa, E. Gomes, E. Rios, F. Ribeiro, J. A (2015). Atuação do profissional de inteligência competitiva. Rio de Janeiro: Publit.

Laudon, K.; Laudon, J. (2010). Sistemas de Informação Gerenciais. São Paulo: Pearson Prentice Hall.

Motta, S. L. S. Oliveira, B. (2007). O marketing ecológico como vantagem competitiva, Revista de Gestão USP, São Paulo, v. 14, n. 2.

Muller, R. Castilho, N. C. J. (2012). Inteligência organizacional como ferramenta de gestão: um referencial teórico integrado. Revista Expectativa, v. 11, 83-102.

Munck, L. Souza, R. B. (2009).Responsabilidade social empresarial e sustentabilidade organizacional: a hierarquização de caminhos estratégicos para o desenvolvimento sustentável, Revista Brasileira de Estratégia, Curitiba, v. 2, n. 2, 185-202.

Oliveria, L. (2004). A estratégia organizacional na competitividade: um estudo teórico. REAd, 40th ed. Vol 10. N. 4. 
Pacheco, F. B.Klein, A. Z. Righi, R. R. (2016).Modelos de negócio para produtos e serviços baseados em internet das coisas: uma revisão da literatura e oportunidades de pesquisas futuras,

REGE,Revista de Gestão, n. 2.

Porter, M. E. (2004). Estratégia competitiva, técnicas para análise da indústria e da concorrência, (2rd. Ed), Rio de Janeiro: (Elsevier).

Silva, C. L. M. Barbosa, S. L. (2002). Estratégia, fatores de competitividade e contexto de referência das organizações: uma análise arquetípica, RAC, v. 6, n. 3.

Silveira, M.Marcolin, C. B. Freitas, H. M. R. (2015). Uso corporativo do big data: uma revisão da literatura, Revista de Gestão e Projetos, Vol. 6, n. 3.

Starec, C. (2006).Gestão estratégica da informação e inteligência competitiva. São Paulo: Saraiva.

Tan, J. (2016). A internet das coisas e a sustentabilidade dos negócios, [Online] Avaliable: https://cio.com.br/a-internetdas-coisas-e-a-sustentabilidade-do-negocio/ (Abril, 12, 2019)

Thompson, A.A. Strickland III, A.J. Gamble, J.E. (2008).Administração estratégica. (15td ed.) São Paulo: McGrawHill.

Whitemore, A. Agarwal, A. Xu, L. D. (2015).The internet of things - a survey of topics and trends, Information Systems Frontiers, 261-274. 